\title{
Looking Good: The Cultural Politics of the \\ Island Dress for Young Women in Vanuatu
}

Maggie Cummings

In "The Hazards of New Clothes: What Signs Make Possible," Webb Keane, discussing the meanings of particular items of clothing, especially those items that come to be labeled as "national dress," asked whether it is enough to see these items as "[mere] emblems of identity." He thought not, explaining, "Too much of the subjective pain and expectation of history centres on changes of dress" (Keane 2005, 5). This seems a fitting note on which to begin a discussion of the island dress- the national dress for women in Vanuatu-and the often-frustrating experiences of young women in contemporary Vanuatu as they attempt to negotiate, through complex and contradictory desires and efforts to "look good," the relationship between national identity, modernity, morality, and gender. Much depends on dress for these women, and looking good is rarely straightforward.

When Vanuatu (formerly the New Hebrides) achieved independence in I980, after seventy-four years of joint rule by Britain and France, the creation of a sense of national identity became a matter of great importance and remains the focus of much contemporary debate. Today, Vanuatu is an officially Christian republic that also prides itself on its uniquely Melanesian cultural heritage and tradition (kastom). In the emergent national imaginary, therefore, discourses and practices of race, modernity and tradition, and morality figure prominently. Ni-Vanuatu (indigenous) women come to embody, both literally and figuratively, the relationship between Melanesian identity, Christianity, and kastom. The face of Vanuatu is that of the mama (mother)-the married, visibly Melanesian, church-going, village-dwelling mother who is respectful of both kastom and Christian (most often male) authority. The mama fashions her identity by wearing an aelan dres (island dress): a shapeless, floral-print frock that Presbyterian missionaries introduced as suitably modest attire for women but that

The Contemporary Pacific, Volume 25, Number I, 33-65

(C) 2013 by University of Hawai'i Press 
was embraced in postindependence Vanuatu as kastom dres blong yumi (our traditional dress). However, the representation of ni-Vanuatu femininity and modernity embodied by the morally upright Christian mother in an island dress, who "looks good," does not go uncontested. One example of this sartorial contestation is the increasing number of teenage girls and young women, especially those living in urban areas rather than rural villages, who choose to wear trousers (usually long, loose surf shorts) rather than the island dress and, in doing so, attempt to redefine what "looking good" means. At the same time, they also attempt to redefine, and re-embody - though with limited success—relationships between kastom and modernity, the local and the foreign, black and white, rural and urban, past and future. Such contestations are often discussed and dismissed in terms of age ("These young troublemakers will dress properly once they get married and have children"), but these generational disputes about proper dress reflect broader social and political economic shifts in Vanuatu over the last thirty years. Elsewhere, I have written about what I call "the trouble with trousers" (Cummings 2005, 2008), with a particular focus on the fact that women who wear trousers are labeled trabol (trouble) and are euphemistically blamed for inviting trabol (sexual assault) when they choose to wear trousers to look good. Here, I focus on the other side of the equation of looking good-the island dress (figure I).

In this article, I draw on insights gathered during approximately twelve months of fieldwork conducted in Vanuatu-mostly in the capital, Port Vila-in 200I-2002 and during two subsequent, shorter trips in 2008 and 20II. I worked closely with ni-Vanuatu fieldworkers from the Vanuatu Young People's Project (VYPP) to explore the contingent and contested boundaries of looking good for young women and the ways in which they negotiate these boundaries. ${ }^{1}$ Using dress as a lens through which to focus on the relationships among gender, modernity, race, and morality, I endeavor to show the ways in which all four are condensed and embodied in the constant duality of meanings and practices of looking good-duality in the sense that looking good is both an aesthetic and a moral imperative for ni-Vanuatu women.

\section{The Island Dress: KASTOM DRES BLONG YUMI? OR STRET FASIN BLONG DRESAP?}

In describing an island dress competition in Port Vila, a human interest story on Australian Broadcasting Corporation $(\mathrm{ABC})$ radio stated: "The 


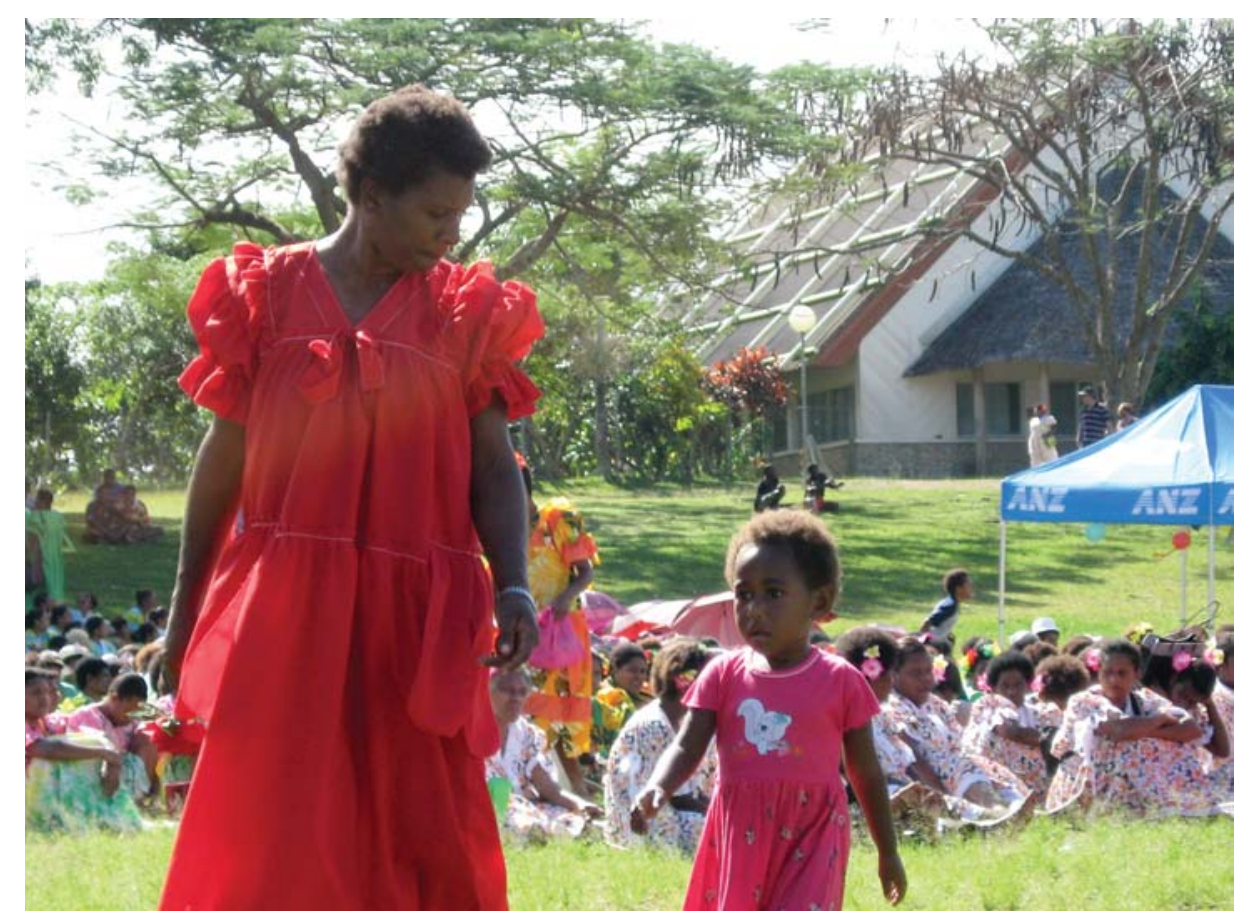

Figure I A mama in an island dress on Saralana Field, Port Vila, on Vanuatu Women's Development Scheme (VAnwods) Open Day, I 8 July 2008. Photo by author.

'Mother Hubbard' or 'island dress' [is] the mother of all fashion statements. Island dress provides a sense of identity, a combination of national costume and everyday wear. Village women often hold impromptu fashion parades, unveiling their latest creations that seem to get more extravagant every year" (Corcoran 2005). But the young women I encountered during my fieldwork, who would more likely be spectators than participants in these "fashion parades," seemed to have a much more ambivalent, love/ hate relationship with the island dress than this description would suggest. The island dress may be closely tied to ni-Vanuatu identity, but many young women do not identify with it. This is not, however, a repudiation of ni-Vanuatu-ness or of the significance of kastom; rather, I suggest that it is indicative of young women's collective desire to redefine what it means to be ni-Vanuatu in the twenty-first century.

In her work with the Women's Culture Project at the Vanuatu Cultural Centre, Lissant Bolton has done much to document the shift of the island 
dress from missionary-introduced coverall to icon of women's kastom since Vanuatu's independence (2003a, 2003 b, 2005, 2007). Her work was part of the broader "Clothing the Pacific" project, which "set out to examine the multiple histories of cloth and clothing in the contemporary Pacific and to investigate how cloth has facilitated both social innovation and resistance during the colonial and post-colonial period" (Küchler 2003). Throughout the Pacific, clothing (especially for women) was a marker of colonial change and Christian conversion, yet Pacific Islanders often appropriated the power of clothing for their own ends (see Colchester 2003; Küchler and Were 2005). The rise of the island dress from its humble-indeed, frumpy-missionary roots to its current colorful and iconic status can be explained by the fact that "soon after Independence, island dresses were officially nominated as national dress for women in Vanuatu. This nomination was taken very seriously by women throughout the country" (Bolton 2005, 26). However, it seems that there has been a shift in the attitudes and practices of the postindependence generation. The island dress may still be the unequivocal national dress for women. But, as Miranda Forsyth pointed out, nationalism in contemporary Vanuatu may be waning after "the excitement of decolonization," replaced by increased "islandism" (affiliation with one's rural island community, even if born in Port Vila) and a deeper, rural/urban divide (2009, 3-4). To what extent, then, do young women still take the island dress seriously as part of an identity project? My research suggests that further inquiry is needed to supplement our understandings of the place of the island dress in Vanuatu today in order to account for young women's intense ambivalence about the dress-evidenced, not least, by my informants' reluctance to wear the dress both in the ethnographic present and in the imagined future. In this sense, my work builds on that of Bolton and of the "Clothing the Pacific" project and focuses in particular on "the hazards of new clothes," especially for youth, within the context of rapid social and economic changes in contemporary Vanuatu. These changes include but are not limited to rapid urbanization; a growing, young population; increased tourism; and high unemployment.

I want to begin by distinguishing between understanding the island dress as kastom dres blong yumi (our traditional dress) and understanding it as stret fasin blong dresap (the proper way to dress). The distinction is a critical one and one that I figured out, after much mental fumbling, with the help of the vYPP fieldworkers. My initial, embarrassingly awkward, half-English, half-mangled-Bislama attempts to discuss either 
national identity or kastom dress were generally met with blank stares or vague talk of grass skirts, respectively. When I worked with Emily Niras and several other youth fieldworkers from the vypp to design an interview questionnaire, they were able to interpret my fuzzy explanations of what I wanted to know into the question that would open all of the interviews we conducted: "Wanem nao stret fasin blong dresap blong ol woman Vanuatu?" (What kind or style of clothes should ni-Vanuatu women wear?)

This is not merely a matter of semantics. My collaborators clearly understood what I had not: that to the extent that the island dress serves as the "official" kastom or national dress of Vanuatu, it does so because its wearers embody and exhibit stret fasin (literally, "straight fashion," or the proper way or appropriate manner). The island dress may be kastom and national dress, but this is a moral imperative above and beyond taking independence and national pride seriously, one in which women, women's bodies, and women's comportment and behavior are deeply implicated. Talking about the island dress as the naturalized or commonsense kastom or national dress for women tends to obfuscate this moral imperative.

In this article I aim to scrutinize and upset the common-sense anthropological and local understanding of the island dress as kastom dres blong yumi ol woman Vanuatu. My research suggests that a more accurate conceptualization of young women's experiences and perceptions of the island dress would be: "Aelan dres hemi kastom dres blong yumi ol woman Vanuatu, but ..." It is the contingencies surrounding the extent to which the island dress "looks good" that are most telling about its meanings and its relationship to modernity, gender, race, and nationalism. There is no singular, straightforward island dress narrative. Rather, contemporary discourses and practices of island "dress-ing" are like those of contemporary kava use as characterized in John Taylor's work on the substance. Both the island dress and kava are "saturated with meanings that evoke complex narratives of nostalgia, anxiety and hope" in diverse contexts (Taylor 20I0, 279). The "ifs, ands, or buts"-often voiced only in couched terms and hushed tones but implied and embodied in everyday practices and concerns of young ni-Vanuatu women-are the focus of this article.

I draw on interviews, workshops, and day-to-day life in Port Vila and elsewhere in Vanuatu in order to reexamine, question, and unpack the nationalist discourse of the island dress. I include some insights from rural women, but my collaboration with the VYPP means that the perspective presented here is the view from taon (town, as the capital is known) and 
from the growing settlements that surround it. The VYPP, based at the Vanuatu Cultural Centre, was established in 1998 to complement and extend the existing focus on contemporary and traditional kastom in rural areas (Mitchell I998) and to explicitly address urbanization and the growing youth population (close to 50 percent of the population was under the age of twenty-five) (Vanuatu National Statistics Office 2000). ${ }^{2}$ As Benedicta Rousseau has pointed out, the expansion of the concept of kastom to include the experience of urban youth, many of whom have never been to their rural island communities, was methodologically fruitful but also exposed uncomfortable tensions about where, and with whom, legitimate kastom knowledge resides (2011, 232-233). Such tensions also animate the contestation over looking good and reflect shifting intergenerational realities.

I present an array of young women's concerns, attitudes, and practices regarding the island dress in their everyday lives. In doing so, I hope to convey some of what Deborah Durham, who drew on the work of Mikhail Bakhtin (I98I) in her discussion of Herero women's dress in Botswana, called the "slippery polyvalency" and "multimodal sparkle" of dress (Durham I999, 390). This polyvalency encompasses what is meaningful not just in terms of interpretations but also in practice and sensibility (Durham 1999). The overdetermination of the island dress as both kastom dres and stret fasin denies this polyvalency-or, at the very least, the generational aspects of it.

I go on to discuss two island dress "spectacles" that demonstrate the ideological and practical clash of the official discourse of the island dress with the "buts" of young women's everyday lives and concerns: the (failed) Shefa province holiday dress competition and the celebrations for National Women's Day. I show that ni-Vanuatu women, especially young, unmarried, childless women, feel a great deal of ambivalence about wearing the island dress and the ways in which it may or may not enable them to look good or to look nice as they see fit.

The Island Dress as Equivocal National Dress:

Ifs, ANDS, OR Buts

\section{Island Dress and Respect}

When asked whether they felt there was a particular way that women in Vanuatu should dress, some of the young women said that women should wear skirts or dresses; a few replied that women should be free to wear 
whatever clothes they wanted. However, the overwhelming majority of my informants insisted that the appropriate style of dress for women is the island dress. When I asked women, "Is there a particular way you think women in Vanuatu should dress?" their answers included:

"Ni-Vanuatu women should wear the island dress because when you wear an island dress, it shows you have respect for your chief and your community. As well, it keeps your body well-covered."

"I think women should wear the island dress. It just looks nicer." [Why?] "I don't know. It just suits us [ni-Vanuatu] better than other clothes."

"Women should be able to wear whatever they want, whatever they feel comfortable in. But I think the island dress looks the best, especially once you're married with children."

In comparing these responses, we can see that, despite the fact that all three women (like most of their peers) immediately responded that island dress was stret fasin or kastom dress, each then qualified her answer, and each did so quite differently. The first answer is the rather canned reply, but it is significant because it references respectfulness. Visibly, undeniably showing one's respect for one's family, community, church, and chief is a major benefit of wearing the island dress-it is above reproach, and women do not have to struggle to be understood or to show their upright moral constitution, their appropriateness, or that they look good because they are good-a common problem encountered by those who choose other clothes. Indeed, the island dress covers many sins. One of the circumstances in which young women claimed that they would readily wear the island dress, and probably the one that surprised me most, was if they found themselves unwed and pregnant with a pikinini blong rod (an illegitimate child). The dress is so loose and billowy that a pregnancy can be hidden well into the third trimester; once a woman is showing, she is already wearing the appropriate clothing for a mother, which takes the sting out of accusations of inappropriateness. This is true even though a sudden change in sartorial habits, from trousers to island dresses, is often an immediate giveaway, at least to other young people, that a girl is pregnant. The appearance of propriety, or of contrition for actual or perceived impropriety, is just as important (if not more important) than actual good behavior. The island dress is synonymous with respect for several reasons: the island dress is long and loose and therefore covers the body well; it neither shows skin nor the shape of a woman's body. The island dress is 
local, traditional dress, rather than foreign or "white" dress, and is a sign of respect for Vanuatu as a unique nation-or, as Lisa Rofel aptly put it, as a nation with a uniquely "Other" modernity of its own (I999). The island dress is traditional dress for women and therefore shows respect for kastom and kastom authority. And the island dress is modest and humble attire and is therefore respectful of Christian dress standards.

The second comment exemplifies the taken-for-granted-ness of the island dress as proper and respectful attire for women and shows the extent to which it is experienced as a symbol or icon of national identity as well as in terms of a bodily and aesthetic sensibility: it just "suits" ni-Vanuatu bodies. This is important to understanding the ambivalence young women feel about the island dress, for, as I show in the next section, young women not only dispute its monopoly on signifying respectfulness but also find themselves in situations in which wearing the island dress just feels wrong, uncomfortable, or impractical—situations in which it does not suit them so easily after all.

The third response is equivocal about the appropriateness of the island dress (women should be able to wear what they want, but they should wear the island dress to look good, especially if they're married); in addition this "but" goes in a direction opposite to many of the other responses I received: I like the island dress, but I don't want to wear it. This is exactly the kind of equivocation I was faced with repeatedly during my fieldwork. Of course, it is also significant that this particular girl cited marriage as the point at which one must wear the island dress to look good. This is not because the dress somehow just looks better on married women; it is because a married woman not only owes respect to her community and her culture but must also respect her partner, who has the option, often exercised, of exerting absolute authority over her wardrobe, or at least trying to do so. Disrespectful dress can incite jealousy, both in romantic partners and in other women. Jealousy is considered the root of gossip, accusations of prostitution, and violence between women and between partners. Such violence and jealousy is so taken for granted that one of the women who appeared in Wan Naes Wan (the film about contemporary young women's lives that resulted from my collaboration with the VYPP [Vanuatu Cultural Centre 2002]) stated, matter-of-factly: "I wear island dresses when I want to look nice and when I come into town [from the nearby settlement] because if I were to wear trousers instead, my husband would be sure to hit me."

Island dress is both respectable and an effective way of dressing in order 
to avoid jealousy, because it is associated with modesty, domesticity and motherhood rather than immodesty, wandering ways, and sexual availability. Even so, many young women choose to wear it only on special occasions. Although they thought it was very nice looking and respectable, they said they preferred to see other people wearing the island dress rather than wear it themselves. Although they appreciated the beauty and national heritage of the island dress, they preferred not to wear it except, perhaps, to church and to special festivities such as weddings or kastom ceremonies.

\section{What Makes the Island Dress "Sparkle"?}

In trying to tie together all of the competing, contradictory, and complex reasons that young women both love and hate (or at least strongly dislike) the island dress, I am drawn to Durham's use of Bakhtin's concept of "sparkle" (1999). Durham explored Herero ethnic dress in Botswana and noted, "Herero often use the dress as an unambiguous, straightforward icon of Herero identity. ... But the full meaning of both the dress and the label was much less assured" (1999, 389). In order to make sense of the dress and all its facets-not just its meaning, but also the color, feelings, sense, and (ironic) sensibility it provoked for its Herero wearers-Durham used and expanded the notion of sparkle to include not just the intended and unintended meanings of various utterances but "the meanings brought by embodied sensibility, as well" (Durham I999, 390). Contested and contestable meanings refract off other meanings, values, and situations and make "the facets of the image [in this case, the dress] sparkle" (Bakhtin I98I, 277). In Vanuatu, the island dress feels one way in church on a Sunday, another way in an island dress competition, and yet another way if one is trying to swim or run away from a group of teenage boys or if one just wants to feel "light" or maybe even sexy. In the next section I include some of my informants' responses to the question "Do you like to wear island dresses?" and then point out how the differences among them can be understood in terms of the different modalities through which meaning, practices, sensibilities, and sparkle are constituted.

\section{"Do You Like to Wear the Island Dress?"}

One key meaning of the island dress, as I have discussed above, is that of overdetermined symbol of national identity, which in turn relies heavily on the ability of the dress, as well as the wearer, to convey respectfulnessrespect for kastom, for one's community and family, for Christianity, and 
for the nation. National identity and respect rely not only on the iconicity and historicity of the island dress but also on the way in which it shapes a woman's experience of her body-particularly as it naturalizes morality as a bodily sensibility. Women who look good in the island dress also carry themselves in a particular way that is read or experienced as good and indeed feels modest, good, decent, respectful, and so on. However, the embodied, sensual experience of the island dress opens it up to meanings other than this dominant one.

Responses to my simple question of whether they like to wear the island dress were anything but simple; women's ways of framing the embodied experience of wearing the island dress provoked uncertainty about its meanings and even defied its usual moral logic. For instance: "I wear my island dresses because my boyfriend gets mad if I wear trousers. I don't like to wear them [the dresses], though. They're too heavy and too hot." In this case, the wearer simultaneously acknowledged that it is respectful to one's partner to wear the island dress and conveyed the idea that the respectfulness of the dress does not emanate from herself or her body in any natural way; she dons the dress for fear of her boyfriend's wrath, not because it feels natural. Indeed, to her the dress feels uncomfortable in the most practical of ways: it is heavy and hot-less than desirable in a tropical climate.

According to another young woman: "When you walk around wearing an island dress, you feel half-naked because it's so big and loose and you have to worry about the wind blowing it up. It's hard to do any kind of work in an island dress, or to sit down and talk with your friends, because you have to worry all the time about whether your legs are covered up or not." The comment is telling because it appropriates the language that is so often used against young women, among others. Immodest and immoral-looking foreigners are often described as walking around "halfnaked" in shorts, miniskirts, or bikinis, which is precisely why it is seen as dangerous for young ni-Vanuatu women to emulate them. Young women are also exhorted to cover up their legs in order to be respectful and modest. However, there is more here than just an appropriation of language; it is a matter of embodiment, of bodily sensibility. It was clear to me, talking to this young woman and to many others, that they really did keenly feel half-naked in an island dress on a windy day, and they really felt that the island dress sometimes lent itself to immodesty rather than modesty. In this sense, both their bodily sensibility and their bodily defiance (by feeling more "good" and more modest in closer-cut skirts, or even trousers) 
adds another layer of "sparkle" to the island dress, one that seems to directly undermine the usual meanings. In the same vein, but perhaps even more telling about and upsetting to the naturalized meanings of modesty attached to the island dress, was this comment: "I don't mind wearing an island dress to church, but I would never wear one just to hang out or walk around, especially at night. If a man tried to chase you and make trouble with you and you were wearing an island dress, he could just grab your dress and hold you down and you couldn't get away because there's so much extra fabric for him to hold on to and it doesn't even block your legs to protect you."

In much the same way that young women described trousers as giving them freedom to run away from potential trabol, many suggested that although the island dress should convey respect and show their modesty, these meanings are not always respected by men with rabis tingting (dirty thoughts or trouble on their minds). My friend Nikki once told a story of running from a group of young men one night on a path through her settlement; she recounted her anger that they were following her and catcalling her when she was dressed modestly, and her genuine fear when she would have to hop a fence, only to have the ribbons on her beautiful dress ensnare her on the barbed wire. She, and the woman quoted in the previous paragraph, felt restricted, unsafe, and even immodest in the island dress. They seemed to suggest that if modesty is natural, embodied, and a matter of comporting oneself in a way that just feels and looks "good," they could be just as good, and just as modest, in trousers. This embodiment of modesty, or modest sensibility, is a form of bodily agency that inverts the usual meanings of the island dress-and trousers.

Many of my informants also implicitly suggested the underestimated significance of the audience for one's performance of ni-Vanuatu femininity. The dominant understanding of the island dress assumes that everyone sees the island dress (and ni-Vanuatu-ness) in the same way-as kastom but not heathen, Christian and therefore modern, but also uniquely Melanesian, not foreign. All of these give it its aura of goodness. However, the young women I knew had a wider variety of audiences in mind:

"None of my friends ever wear island dresses, so if I wore one, I'd feel weird and out of place."

"I wear my island dresses to church, but I don't like to wear them to work because I think it looks more appropriate to wear Western-style dresses for work." 
"When I was a little girl I used to wear island dresses, but now I don't really like them because I feel like when I put an island dress on I look like somebody's mother. But someday when I have children, I guess maybe then I'll like to wear island dresses because they look good if you're a mother."

"I don't like to wear island dresses because when I wear one, I feel like I look fat. I'm afraid that if I wear an island dress all the time, I'll actually get fat. I don't want to look like I'm pregnant, and I really don't want people to suspect that I am pregnant when I'm not. Even when I get married, I don't think I'll wear one because I don't want to look fat. It only looks nice if you're tall and thin.”

In each instance, the audience for the island dress is complicated and problematized. In the first, the audience is other young people. In the second, the gaze, real or imagined, is that of the foreigner-an audience whose gaze is becoming more salient, especially in town, as more tourists come to Vanuatu and as more expatriates buy land, start businesses, and hire ni-Vanuatu employees. Both audiences are deemed problematic in the dominant discourse of the island dress and national identity; young women who care too much about these audiences, rather than showing respect for their elders, are labeled flas (showing off). However, neither of these first two speakers, in addressing her respective audience, seemed to express (nor, when I talked to them, did they appear to embody) the kind of stubborn, disrespectful, or self-centered sensibility that accusations of being flas convey. Rather, they expressed a sense of inadequacy, of not measuring up or fitting in. Moreover, it is worth noting that even the most defiantly dressed young woman rarely stands out from the crowd, at least in town. Rather than dressing to express individualism, young women want to join a new sartorial collective-dressing like other town-dwelling youth, boys and girls alike. In this sense, wearing trousers has much in common with the island dress and other forms of collective dress throughout the Pacific.

In the third and fourth examples, not only is the audience problematized, but so, too, are the criteria by which the anticipated audience would read the dress-the women were ambivalent, at best, about being seen as mothers or as expectant mothers. When they questioned the takenfor-granted goodness of looking like a mother, they were neither questioning the value of motherhood nor denying that mothers do deserve the respect that they get. However, they did convey their own frustration 
that there seemed to be no other way for them to earn, or even imagine earning, respect as ni-Vanuatu women, except as mothers. Although they struggle constantly to perform respectfulness, they know that they cannot expect to be respected themselves until some vague future when they have children. Nonetheless, they cannot necessarily imagine wearing the island dress when they have children. But the island dress is so closely tied to respect that it is hard to imagine how they can have the one (respect as mothers) without the other (wearing the island dress) — which, as we have seen, they do not necessarily feel like wearing or "feel good" in.

The frustration about the equation of the island dress with looking good is felt keenly by young women, more so than by their mothers (and, generally, by women who came of age during the era of Vanuatu's independence) because these older women already embody goodness. Looking good was created in their image. In order to look good and feel good about themselves, young women want to look modern, comfortable, and sometimes even sexually attractive-and not to look fat, pregnant, or like someone's mother. The chiefs, pastors, and others who chastise young women choosing to wear trousers or other "foreign" clothes are right: the youthful aesthetic turns away from the past, toward development and to influences outside Vanuatu. However, this does not necessarily mean that young women are inherently disrespectful, and this seems to be where meanings, practices, and sensibilities do not fall neatly into place. For mothers-and really, only for a mother of a certain age and aesthetic-looking good involves dressing in an island dress to symbolically emphasize women's roles as mothers, as role models, and as teachers of traditions. The aesthetic of motherhood is one that focuses on continuity with the past, maintenance of tradition, and indigenous values, which include being a good Christian. The troublesome or dangerous aesthetic of the young woman, in contrast, looks forward to the future, though young women try to imagine and look forward to alternate futures for themselves even when they are wearing the island dress. Young women, I believe, are in a liminal position; exhorted to maintain the past but told that they will be most respected when they are mothers in the future, they are then expected to dress like mothers in a way that embodies the past. Put another way, one might say that the island dress is linked not just to the past but also to a certain vision of future. After all, as Taylor pointed out, both kastom and modernity are Janus-like, referencing the past but oriented toward the future $(2010,285)$. It is not that young women cannot imagine individual futures in which they will have children. Indeed, 
most of my informants have had several children since I first met them, yet few have "switched" to wearing the island dress. Rather, they are uncertain about the future. As young women living in town, without access to land or gardens, they worry about whether they will find work and be able to afford work-appropriate clothes, not about whether those clothes embody national pride.

In the next two sections, I show how the competing, contradictory, and unequal "sparkling modalities" of the island dress played out in the realm of spectacle-in island dress fashion shows. Elsewhere in the Pacific, anthropologists such as Kalissa Alexeyeff (2008) and Niko Besnier (2002) have analyzed beauty pageants in the Cook Islands and Tonga, respectively, in terms of tensions between the local and the global. Here, I focus on the contested narratives and meanings of kastom, gender, and modernity that were on display.

\section{Shefa Days: The Fashion Show That Never Happened}

I heard and read many enthusiastic accounts, such as the ABC story excerpted earlier, of the popularity and ubiquity of island dress competitions and shows, which are often held by women's organizations, church groups, for fundraisers, and so on. But I have never seen such a competition myself. I made it clear to anyone who would listen that I was very eager to see one, but the events were just not as ubiquitous as I had expected. The only occasions that came close were two state-sponsored spectacles-the parade and festivities for National Women's Day and an island dress fashion show that was part of five days of festivities to celebrate the Shefa provincial holiday. The ambivalent mood of the Shefa Day fashion show/island dress competition stood in stark contrast to the ebullient tone of National Women's Day, but both events highlighted the causes and characteristics of the frustration and exclusion of young women's experiences of the island dress.

The I8th of June is Shefa Day-a provincial holiday in celebration of the people, kastom, and achievements of ni-Vanuatu from Shefa province. Each of Vanuatu's six provinces marks its provincial holiday (a day off, unofficially at least, for those people from that province who are also lucky enough to have waged employment) with a festive public gathering. Because Shefa is home to Port Vila and to most of the population, in 2002 Shefa Day had been expanded into Shefa Days and was billed as a five-day extravaganza featuring sports tournaments, performances, food 
stalls, and speeches. It took place at Kawenu Field on Malapoa Point, an outdoor sports complex of sorts with a large football field, bleachers, a basketball court, and a stage.

There was much anticipation of the Shefa festival in my adopted household, which was situated near the site. Mother Joanne, ever the entrepreneur, had booked a food stall and was looking forward to five steady days of work close to home, rather than having to go all the way into town to sell food at the market as she usually did. When she heard about the fashion show, she also took to her sewing machine-she hoped that if she won, she might be able to attract clients as an island dress seamstress. It is worth noting here that she had little luck on this front, perhaps because so many of the attendees were unemployed young people. Island dresses require several meters of fabric and are relatively costly compared to the other clothes on offer in town, which were also more appealing "modern": relatively high-quality secondhand clothes for work or special occasions and cheaply made boardshorts and T-shirts from Chinatown for stylish everyday wear.

Determined to sell food and win the fashion show, after spending most of the day cooking Joanne worked at the kitchen table on her sewing machine well past midnight several nights in a row. On the other hand, Max, the father, had low expectations for the festival and predicted disorganization and poor attendance. Their teenagers were looking forward to having something fun to do-watch and play sports, hang out at night, see other youth from around town-all within walking distance and therefore not requiring bus fare. Even Jody, the house girl (domestic worker), was excited, even though she would be helping Joanne with the cooking in the sweltering heat of the food stall.

I was looking forward to what the organizers touted as the main event of the festivities: an island dress fashion show. The competition would pit women and their handiwork, as well as their comportment and demeanor, against each other. Shefa province is the unofficial "home" of the island dress. The dress has Presbyterian roots, and Shefa is an overwhelmingly Presbyterian province. According to Bolton, "The island dress was most extensively adopted in central Vanuatu [Shefa]. In these areas, the dresses have their own local language name, and they have a remembered history of transmission that is entirely indigenous. Island dresses are deeply incorporated into local practice in this part of Vanuatu; they no longer seem to be something from outside" $(2005,22)$. Although in my experience younger women in particular associated the dress with national, 
rather than local, identity, the idea that the dress had originated in central Vanuatu did have some resonance, particularly within the context of Shefa Days. I was excited to see what everyone assured me would be a grand display of national and provincial sartorial pride. My excitement did not seem misguided; plenty of other people, especially those ni-Vanuatu who were familiar with my research interests, told me that I “mustn't miss out" on this fantastic opportunity. Because they knew that I was working on a video project with the VYPP, they encouraged me to get the camera and record the event for posterity-and help to insert such contests more firmly into the realm of kastom.

On the first day of the festival, the emcee began the day by eagerly promoting the event, calling for potential competitors to sign up for the contest, which was scheduled for the evening. After spending a few hours watching youth play football and waiting for something to happen (we were, as my young friends would often complain, "just being boring”), I heard that the organizers had postponed the fashion show. They reasoned that it made more sense to save the competition for Shefa Day proper, the third day of the five-day festival, because people would have the day off work and, therefore, there would be more contestants and more spectators. Joanne was glad to have the extra time to sew a winning dress.

The second day of the festival was uneventful and not very well attended. Perhaps Max had been right; things were poorly organized and there was not much to do. Joanne was frustrated that there were so few customers at her rented food stall. The festival organizers postponed the island dress fashion show again on day three and day four. On the fourth evening, the emcee declared that the fashion show would be such a highly anticipated spectacle that they were saving the best for last. On day five, the starting time for the show was repeatedly pushed back in hopes of increasing attendance. By late afternoon, there was a substantial crowd, and, luckily for Joanne and the other mamas, business was finally brisk at the food stalls.

Around 5:00 PM, the emcee announced the imminent beginning of the fashion show. He called all the participants to come and change into their dresses. Accompanied by a vYPP fieldworker armed with the video camera, I made my way toward the stage, looking for the best seat for the show. As the contestants changed, someone started playing Radio Vanuatu over the loudspeakers. The music was a mixture of local reggae and imported pop. For the first time during Shefa Days, there was palpable energy and excitement in the crowd, and a few adventurous souls (mostly young people-in 
fact, mostly young men) started dancing. The emcee kept trying to get people to stop dancing, repeatedly yelling "Sidaon!” (Sit down!), but instead, the makeshift dance floor started to grow. The dancers only stopped when they realized that there was going to be a dance performance before the fashion show. Once everyone sat down, a coed group of teenagers dressed in matching outfits that made them look like a cheerleading squad recreated the dance from the latest Vanessa Quai video. ${ }^{3}$ The crowd, especially the young people who had been dancing, were appreciative of the performance, shouting and clapping along.

Finally the emcee told the rest of the people at the festival to make their way to the grandstand because the fashion show was about to begin. As is customary, the show began with a speech, in which the speaker noted the significance of the island dress, especially in Shefa province. She pleaded with the young women of Shefa not to deny their local identity by thinking that the island dress was for mamas only. A young woman herself, she captured something of the uneven sparkle of the island dress as an identity marker: she spoke in the language of denial or loss of identity but also managed to point out surreptitiously that it feels awkward for young women to claim the dress as their own when it is so closely associated with motherhood.

After the speech, the show began-and quickly ended, as there were only five contestants. In fact, initially, there were only four; a fifth and final woman joined in from the audience. The other four contestants were women I knew: Joanne's daughter Suzanne, her sister Rachel, our neighbor Roslyn, and the daughter of one of the administrative staff at the Vanuatu Cultural Centre. Each woman took her turn on the makeshift catwalk; each smiled widely while casting her eyes modestly toward the ground, spinning in circles and flaring the skirt of her dress in order to make it billow and sway. Suzanne and Rachel, their hair wreathed with faux-hibiscus wreaths from Chinatown, were wearing the dresses that their mother had made-one was green with yellow ribbons and the other was pink with white ribbons and even a white lace underskirt. They were beautiful dresses. Roslyn's dress, which Joanne had also made, was a wedding dress-white, with petticoats, and festooned with lace. Roslyn wore a matching wreath of white hibiscus and silver tinsel. The fourth contestant, a crowd favorite, was wearing a dress in the colors of the Shefa flag. Finally there was the last contestant, who had entered the competition with her everyday dress. The entire show lasted only ten minutes. We had to wait, again, for the judge's decisions. Two hours later, after more 
dancing in the interval, the emcee announced the winner to those audience members who were still paying attention. First place went to the lastminute entrant; the Shefa-flag dress placed second; Suzanne and Roslyn tied for third; and Rachel was fourth. ${ }^{4}$

At the time, I found the situation devastatingly anticlimactic. How could there be so much buildup, so much genuine anticipation, for an island dress competition in which the only participants were people I knew? Had I not been there, and if no one had known about my research, would anyone have participated at all? The hype about the show seemed to have been all talk and no action. However, in retrospect, I see that the entire Shefa Days experience elevated to the level of spectacle the ambivalence toward the island dress that young women professed in my interviews. Indeed, although the island dress competition barely happened, what did happen was very telling about the way in which the island dress plays into more everyday concerns.

My first clue that the island dress competition would be both more and less than it was made out to be was the fact that it was repeatedly referred to as a "fashion show." The notion that "fashion show" conveys-of showing off both one's body and one's knowledge of the latest trends in clothes-does not fit well with the usual norms of the island dress competition. Fashion turns its seemingly insatiable gaze to the future, to progress, and, in Vanuatu, to the foreign, none of which applies to the island dress as an emblem of national identity. Island dress competitions are more often fasin (nature, fashion, or manner) shows-about proper comportment and the embodiment of a modest, Christian, respectful sensibility. In many ways, especially for those youth who made up the majority of the attendees, this particular festival was not conducive to performances of stret fasin, at least not in its strictest sense. There were too many opportunities for young people to show off, to mingle and flirt with the opposite sex, to dance, to play sports-and therefore, for women, to wear trousers-and to stay out late. I think that part of the excitement, at least among the young people I knew, lay in the fact that the island dress show would provide an alibi of sorts, conveying legitimacy on an event that otherwise presented myriad chances for youth to get into trouble.

However, I want to stress that even if the island dress show was an alibi, it was not because ni-Vanuatu youth were looking for opportunities to be troublesome, to behave badly, to comport themselves indecently, or to be disrespectful. It was simply a chance to kill time or to stop 
"being boring," if only for a few days or even one night (see Mitchell I998). For instance, after the island dress show, the lights were shut off, the music was turned on, and the dancing began anew. Because it was now a little later, and much darker, everyone was a little bolder; nonetheless, this was not a crowd of dangerous raskols or hooligans by any stretch of the imagination. Although both boys and girls were dancing, they were dancing in single-sex groups. When one boy did sidle up to a crowd of girls and try to dance with them, he was quickly put back in his place by the girls, who accused him of being "like a dog" and yelled at him to go home.

What was most striking about the entire scenario was the extent to which everyone was watching each other, scoping out the crowd, trying to see what people were up to while remaining unseen themselves. Initially, I felt conspicuous wandering around in the dark, trying to observe what everyone was doing. However, I realized soon enough that that was what everyone else was doing, too. Eventually, Jody, the house girl, left the stalls where she had been helping with the cooking and came to find me at the edge of the crowd of dancers. We decided to wander through the crowd together. I was apprehensive as we walked farther into the dark and into the crowds. Jody and I were holding hands, and I suddenly realized that she was clinging just as tightly to me as I was to her. She turned to me and said, "I'm a little bit scared. I've never seen this many people in one place before." Jody had only recently moved to Port Vila from a small village on the northern island of Malakula. We were both protecting each other, it seemed, from the unknowns inherent in such a large gathering of so many different youth from so many different villages, islands, and backgrounds. The presence of youth and cultures from different islands is often one of the reasons cited for restricting the freedom of movement of young people to and from Port Vila-there is a fear that everyone, not knowing which rules to adhere to, will run amok, without any sense of whose kastom to follow should something go wrong. However, the young people I observed were, for the most part, apprehensive, cautious, and as respectful as possible in their movements and behavior. It is this aspect of contemporary urban youth culture in Vanuatu that I think underlies the ambivalence about the island dress. The island dress aligns itself symbolically with stasis, and timelessness, in a way that just does not reflect the reality of life for many young people in Port Vila. Island dress is supposed to be stret fasin blong dresap, but in Port Vila, especially for young people, it is often difficult to know what, exactly, stret fasin entails. 


\section{National Women's Day: Uneven Mimetic Terrain on the Dress-Scape of Vanuatu}

The final, but perhaps most significant, modality of the island dress's "sparkle" arises from its mimetic qualities as well as the mimetic performances of those who wear it and even those who do not. As mentioned above, the island dress was originally introduced locally as the Mother Hubbard, and although it was a copy of a nightgown belonging to a white missionary, it has since become kastom dres blong yumi ol woman Vanu$a t u$. Today, the island dress is considered authentic and unique, and it is used to mark the moral and cultural difference between ni-Vanuatu and others, especially white foreigners - as well as ni-Vanuatu superiority. The island dress as kastom dres blong yumi reiterates the historical moment when ni-Vanuatu ceased being heathens and acknowledged "the light," but it does so in such a way as to assert ni-Vanuatu claims to authority in areas of morality, kastom, and Christianity. In this case, the island dress exemplifies the subversive potential of the copy.

But if the island dress in Vanuatu is subversive, why did so many of the young women I knew insist that they did not like to wear it because it just did not suit them or look good on them? Why did they go on to insist that while they would not be caught dead in it, it looked great on me? What should I make of the fact that my expatriate friends held smashingly successful island dress parties, during which both women and men took great, drunken delight in copying the women who sport the dress that was originally intended as subjugation, to visibly indicate that ni-Vanuatu should endeavor, at least during the colonial era, to look "white but not quite"? The lines between subversion and subjugation (of younger women to their elders and to masculine power and authority glossed as kastom; of ni-Vanuatu in relation to wealthier, white foreigners) are hard to define in the case of the island dress. Perhaps the ambivalence my friends and informants felt about wearing the island dress can also be understood as a response to the uneven mimetic terrain on the dress-scape of Vanuatu, where some copying is good, some is bad, some can be read as parody, some as irony, but the power to say which is which is rarely in the hands of young ni-Vanuatu women. Events that occurred during the National Women's Day festivities showed just how stark the ambivalence about the island dress can be, and how much of this ambivalence is created by the uneven mimetic terrain. 


\section{National Women's Day: Who Wears the Island Dress?}

The I 5 th of May is National Women's Day in Vanuatu, and the theme for the 2002 celebrations was "Strengthening Women's Participation in the Nation." The day began with a parade along the main thoroughfare in Port Vila. I saw many parades while I lived in Vanuatu, ${ }^{5}$ but the National Women's Day parade was by far the biggest, both in terms of the size of the parade and the number of spectators. People lined the streets and balconies and joined in the chants of "Luksave wok blong woman Vanuatu" and "Respektem wok blong woman Vanuatu" ("recognize" and "respect" women's work and contributions, respectively); many even joined the march as it passed, although at least one group of teenage boys joined in a counter-chant of "Luksave wok blong man Vanuatu." The parade participants included school groups, representatives from businesses and unions, members of the Vanuatu National Council of Women, and representatives from the Ministry for Women's Affairs, each demarcated not by floats but by groups huddled around banners with a variety of slogans.

The majority of the participants in the parade, however, were women's groups from at least a dozen different church congregations. I was able to count the number of distinct church groups not only by their banners but also by their appearance: all of the members of each group wore matching island dresses, brand new and tailor-made for the occasion. Although there was no formal competition between these groups for the "best-islanddressed," the atmosphere was definitely one of friendly rivalry. The island dress is modest, but it is rarely plain; the dresses for this special occasion were bedecked in all manner of fancier-than-usual trimmings-lace woven of glittery thread, long sleeves, extra-large wings, even Christmastree tinsel. Once the parade had made its way to Saralana field outside the Vanuatu Cultural Centre and the speeches and performances had begun, the island-dressed women were able to compare dresses and admire each other's handiwork in earnest. None of the usual concerns about showing off, being immodest, or provoking jealousy were in evidence. These women showed off and danced with abandon and were clearly there to see and be seen as much as to celebrate National Women's Day.

I attended the festivities with the vypp fieldworkers; the Vanuatu Cultural Centre asked us to practice our video-making skills by filming the events. I had first heard about National Women's Day from Joanne, who had been working on her island dress for weeks. National Women's Day, 
she said, was the day when ol woman oli pleiplei (women get to have a good time).

She was not exaggerating. When Vanuatu's only all-woman string band took the stage and launched into their version of the island dress song, the crowd went wild. "Aelan Dres," a musical tribute to the beloved frock, was released by Dausake, another local string band, shortly after I arrived in the field in $200 \mathrm{I}$, and it was immensely popular. I heard the song easily five times a day-and whenever it came on the radio, people would exclaim “Awo-Aelan Dres!" and sing along. The lyrics, which sing the dress's praises ("You're colorful, you make everyone happy, you swing around, our Island Dress"), clearly spoke to people, and to hear it played by a women's string band-themselves decked out in matching island dresses with flashy wings and fancy sleeves (figure 2)-was that much better. I stood with the workshop participants as they filmed the crowd of cheerful women dancing in their cheerful dresses-which, spinning around, resembled nothing so much as a bunch of open cocktail umbrellas. When the song was over, there were cries of "Plem bakegen!" (Encore!), and the band proceeded to play the song again and again and

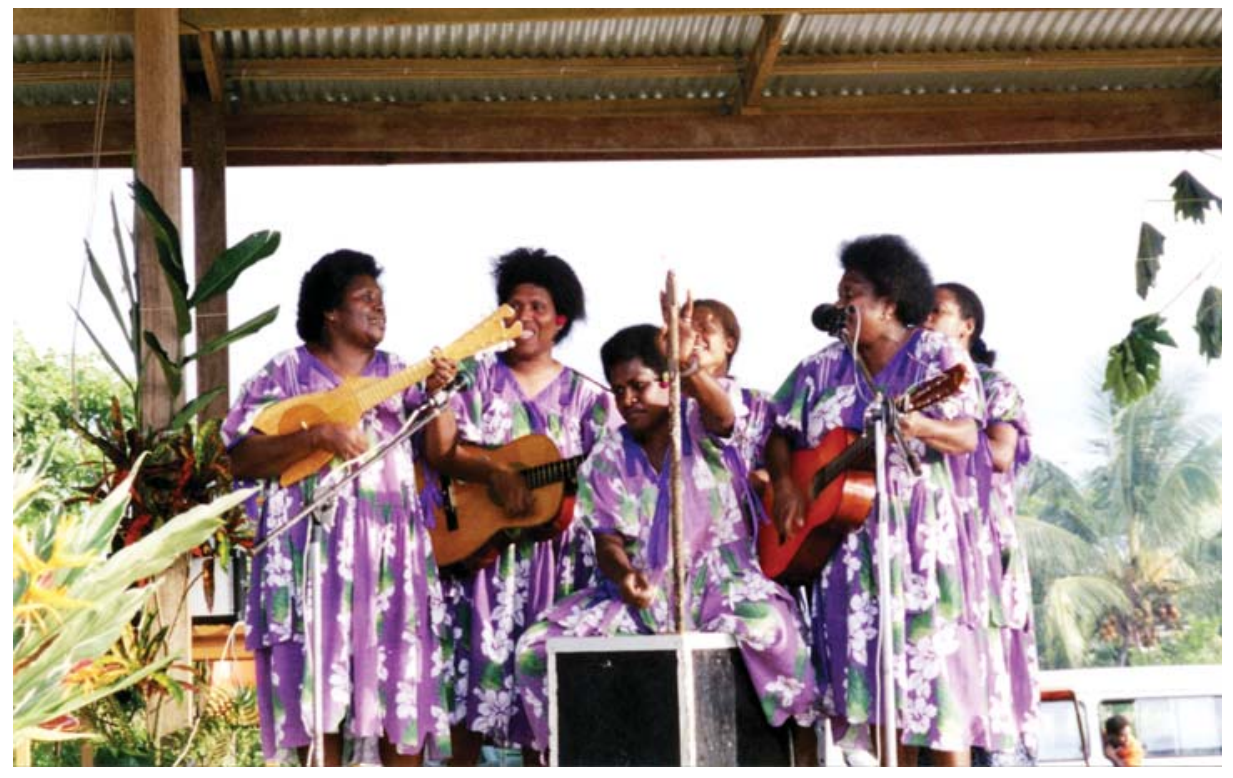

Figure 2 An all-woman string band performs the "Aelan Dres" (Island Dress) song on Saralana Stage, Port Vila, on National Women’s Day, I 5 May 2002. Photo by author. 
again. Each and every time they launched into those opening chords, the crowd was just as ecstatic (figure 3). In retrospect, the carnivalesque atmosphere and unreserved dancing of the mamas were in marked contrast to the reserved, cautious, and mostly respectful youth dancing after the Shefa Days fashion show.

But there remains another side to the story. Amid the sea of fruity cocktail-umbrella dresses, my friends from the workshop were also dancing, singing, and showing off, clearly loving the spectacle of it all. However, I was the only one showing off my island dress. When we were approached about filming the day's events, the prospect of having to wear island dresses-which I had taken as a given, since it was a special occasionhad nearly been a deal breaker. A small contingent of the more outspoken girls had asked me, "We won't have to wear island dress, will we?" Suzanne actually snorted and said, "You can wear whatever you want. I'm going to wear pants because I want to be comfortable." As I sweltered in my island dress and tried to prevent my swirling skirt from blowing up over my head like an inside-out cocktail umbrella, the rest of our makeshift film crew danced, too, but in their "comfortable" clothes of choice:

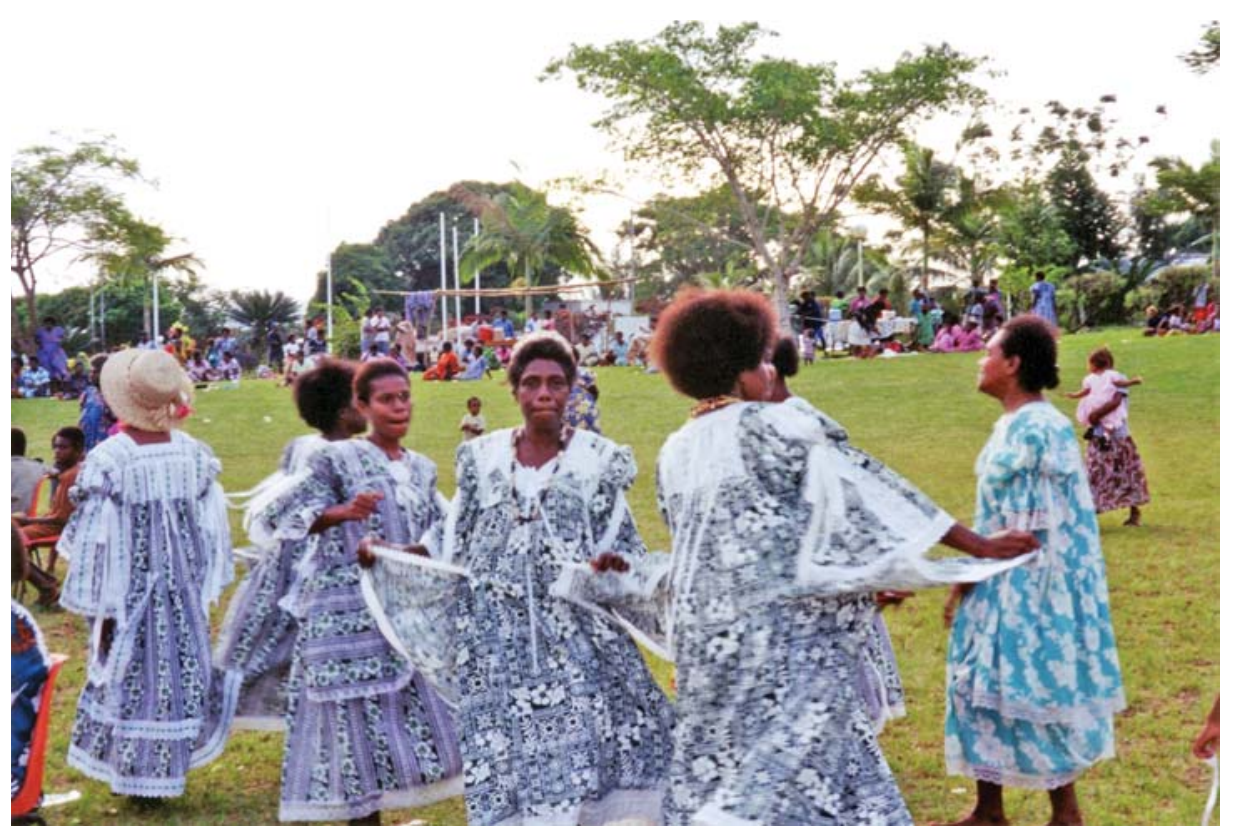

Figure 3 Ol mama (mothers) dancing to the "Aelan Dres" song on Saralana Field, Port Vila, on National Women's Day, I 5 May 2002. Photo by author. 
long boardshorts and baggy T-shirts. Suzanne and her sister were actually wearing my clothes, pillaged from the closet that morning after much careful debate. Who was copying whom? And why?

It is worth noting that when they told me how much they liked my dress, the girls were not simply making fun of me. On days when I wore my island dress, complete strangers would sing out their appreciation in the streets. I also know my friends were not making fun of the dress because they did make relentless fun of my attempts to join the dancing. My informants frequently compared the way they imagined the dress looked on their bodies to the way they felt it looked on me. A typical interview in which a young ni-Vanuatu woman contrasted our sartorial choices might have sounded like this:

Maggie Cummings (MC): What kind of clothing makes a ni-Vanuatu woman look good?

Young woman $(\mathrm{YW})$ : To look good, women have to wear an island dress.

MC: Can you tell me why?

Yw: Because it shows you're a good Christian woman, who has and shows respect, and because it's kastom dres blong yumi.

MC: Oh. I see you're not wearing an island dress. Why not? Does that mean you don't look nice?

YW [scrunching face]: Me, I don't like to wear the island dress all the time. It's too hot and it makes me feel fat and uncomfortable. Some people look good in it, but I don't like it. It doesn't suit me. But all ni-Vanuatu women should wear it to show respect for church and kastom.

MC [looking down at my own island dress, mortified]: Oh. I must look so ridiculous and fat in this dress. You must think I look terrible.

Yw: No-Yu luk naes we i naes! I fit long yu! Be mi, long tingting blong mi, mi no laekem nating! (No! You look really, really good! It suits you! But for me, in my opinion, I really don't like it at all [for myself].)

It is relatively easy to understand why the island dress has becomes such a powerful emblem of national femininity that even young women who cannot stand to wear it can insist that it is a prerequisite for looking good. It has a definite "Take that!" quality to it-no longer mere copycats, niVanuatu women clearly outdress the white tourists, development workers, settlers, and anthropologists and outdo them as good Christians.

So, how to explain the often-intense dislike of the dress? What makes 
the island dress subversive is, paradoxically, also what makes wearing it such an angst-ridden experience for my informants. Especially for the earlier generation of women who came of age around the time of their country's independence, the island dress strikes a balance between kastom and modernity. Its wearer invokes the moment when ni-Vanuatu left their heathen past behind and became modern by becoming Christians, while at the same time embodying kastom because it is so decidedly neither foreign nor a "white" dress. However, I would argue that the young women I worked with feel a renewed pressure to look good in a way that "fixes" the ultimately unfixable relationship between kastom, modernity, and ni-Vanuatu cultural identity. Trying to look good puts ni-Vanuatu women in a precarious situation vis-à-vis modernity and tradition. On the one hand, young women who choose to wear shorts and T-shirts are accused of destroying kastom, of being too modern, and of trying to look and act olsem misis (like white women). On the other hand, whether they wear shorts or island dresses, young ni-Vanuatu are often judged by (mainly white) expatriates and tourists as hopelessly out-of-date, even backward. When island-dress party revelers drink and curse and smoke and fool around while wearing the dress of the Other, they are poking fun at what they see as Vanuatu's misguided and outdated Victorianism. This instance of interracial parody puts the ni-Vanuatu woman back in her place and counters the pride with which some women today wear the dress by instead suggesting that their copying is hopelessly behind the times. ${ }^{6}$ To add insult to injury, when young women defy their chiefs and transgress sartorial gender norms by wearing baggy surf shorts and oversized T-shirts-which to many is the kind of gender transgression that proves that white women are morally inferior - they are seen by expatriates and tourists as still getting it wrong by wearing unflattering men's clothes. What neither the chiefs nor these expatriates recognize is that youth, especially in Port Vila, while surely influenced by and drawn to "foreign" clothes, are not so much trying to emulate expatriates as they are trying to make these clothes their own and to mark a new sense of youthful, urban, modern-yet-respectful collective identity. Looking good for ni-Vanuatu women is all about embodying modernity, racial identity, appropriate femininity, and morality-and the precariousness and contradictions left my informants in a state of constant frustration.

Having made a little sense of the ambivalence surrounding the island dress, I want to consider briefly what is being negotiated when my informants insist that I look good when I wear the island dress, while in the 
same breath they surely say it does not look good on them. Why did people's faces light up, why did they sing out to me? I want to believe that they meant it, to take their words at face value. Ni-Vanuatu heartily appreciate gestures toward sameness-when expatriates eat island food, try a shell of kava, or come to church. I do think that, for a moment at least, seeing me in an island dress did make people happy and that they did think I looked nice. However, I agree with James Clifford that "moments without irony are evanescent" (200I, 258). The moment of seeing me, the anthropologist, genuinely looking good in "their" dress is fleeting, for at least two reasons. First, the insistence that I look good in the island dress might just as well be an insistence that, as a morally suspect, too-modern foreign woman, I did not look good the rest of the time. Perhaps my copying of proper and modest dress might be a sign of my conversion to more properly Christian, respectful ways, and an indication that my friends had been a positive influence on me.

Second, as James Fernandez and Mary Huber have put it, "The subtle power of irony may lie precisely in its ambiguity with regard to the true position of the speaker, marking an ambivalence about the self which is a key feature of the postcolonial condition" (200I, 28-29). I think that my informants' insistence that I look good in "their" dress has to be read ironically, not least because it is just not true: few people really look good in an island dress, and I looked positively ridiculous. The insistence that I look good highlighted the enormous gap between my mimetic performance of ni-Vanuatu femininity and the day-to-day lives of my informants. I could put on the dress for a day and evoke smiles and singing. The next day, I could wear pants, or skirts, or a bikini if I wanted to, and no one would say anything about it—at least not to my face. Moreover, I could easily afford the expense of a tailor-made island dress and, indeed, a closet full of high-quality trousers, shirts, and dresses of the sort that most of my friends could only dream of or perhaps buy secondhand, when they had a little cash. My informants, on the other hand, could either feel old-fashioned, out of fashion, and uncomfortable in an island dress or wear trousers and risk being chastised or ostracized. In either case, in attempting to negotiate tradition and modernity, they would be in the position of being cultural copycats. What they could never really copy, even though it really "looked good" to them, was my relative freedom to wear whatever I wanted without fear and to buy my clothes from a seamstress, a secondhand store, a Chinese shop, or one of the more expensive stores aimed at the increasing number of tourists. That is why 
I think the moment of looking at each other's clothes and sizing up each other's performance of femininity has to be read with irony. To borrow from Clifford again, "Irony is a means of getting some purchase on slippery power" (200I, 255).

\section{Conclusion: Race, Gender, and Uncertain Futures}

In The Meaning of Whiteman: Race and Modernity in the Orokaiva Cultural World, Ira Bashkow explored the way that the Orokaiva view and understand the people they call "whitemen" (2006). He stated that, rather than worry that his own presence as a whiteman would somehow distort his findings, he made a methodological choice to "embrace [his] own whiteness as a research tool in studying the views of whiteness held by [his] black informants, to whom [he] was definitely saliently, white, developed, western" (Bashkow 2006, I 5). Elsewhere, I have written about the methodological conundrums I faced as a white woman and anthropological "expert" working with young women at the VyPp (Cummings 2005). Here, I want to take up Bashkow's definition of whiteness as referring to more than just physical characteristics but also technologies, foodstuffs, activities, abilities, and obligations or lack thereof (Bashkow 2006, I2). In doing so, I want to push this definition a step further: whiteness was salient to ni-Vanuatu as foreign, developed, and modern, but it was also significantly gendered. To my informants, my whiteness and my gender were read in a particular way: I was free to buy and to wear whatever I wanted, but I was also free to move around Port Vila, and around the world, wearing whatever I wanted, without a chief or pastor or brother or any other man telling me what to do and without fear of gossip or reprisals. If Bashkow uncovered, through his methodological embrace of whiteness, "how Orokaiva morality is reflected on whitemen's skin" (2000), then I discovered how ni-Vanuatu perceptions of morality are reflected on whiteman's (or whitewoman's) skin, further refracted on the gendered body, and experienced and embodied by young ni-Vanuatu women as looking good. A focus on the relationship between morality and aesthetics, and particularly on dress, further complicates the notion that folk conceptions of race are symbolically anchored not so much to bodies and persons as they are to "areas other than persons" (Bashkow 2006, I2) - in this case, to the island dress. Clothes are special because they mediate between the self and society (Hansen 2000, 4); as "social skin" (Turner I980), they mediate between embodied selves and collective identities. A focus on the 
dressed body enables a unique perspective on the relationships among race, gender, and modernity.

In the example from National Women's Day, I was physically present in my whiteness, even when I was wearing an island dress. Whiteness was also a meaningful presence when Suzanne and her sister wore my clothes to the spectacle. The specter of whiteness is always present in the dressed ni-Vanuatu body and in discourses of national identity and femininity. For one afternoon, however briefly, Suzanne and her sister were able to gain purchase on the slippery power of whiteness. At the very least, they displayed their power over me (and their association with my relative powerfulness) by triumphantly wearing my clothes for all to see. Furthermore, when they temporarily tried on whiteness, they exposed an uncomfortable but crucial power dynamic that might otherwise have remained hidden: I had the power to shift the meanings of wearing an island dress from appropriate performance of kastom to appropriate appreciation of kastom. Suzanne, her sister, and all of the young women who attended the National Women's Day parade and festivities that day are aching for a chance to show their appreciation of and respect for kastom without having to wear the island dress-and while having the freedom that I had to wear whatever I chose. They did not get that chance: at an event that was meant to be about "Strengthening Women's Participation in the Nation," these young women were neither part of the celebration nor part of the spectacle. Instead, they were made spectators and, in some cases, videographers. Young women seek "recognition" as full-fledged citizens of Vanuatu but struggle to "orient their sensual, emotional, and corporeal identities" (Povinelli 2002, 8) toward the nation's image of kastom, for example, by trying to be respectful and feel free and comfortable, without going off script. When it comes to nation building, national identity, and national pride, it is not clear how or whether young women are supposed to participate in the present; it seems that they must wait to participate as the mothers of the future (figure 4).

However, like kava, the island dress, especially for young women in Port Vila, "speaks of social relations in turmoil and uncertain futures" (Taylor 20I0, 279). As noted earlier, most of the young women I spoke with during my initial fieldwork are now married mothers themselves. Nonetheless, they have not taken up the island dress as everyday wear, preferring still to save it for church and other special occasions. However, this is not a disavowal of the significance of the dress in the national imaginary, of the value of kastom, or of the importance of respect and 


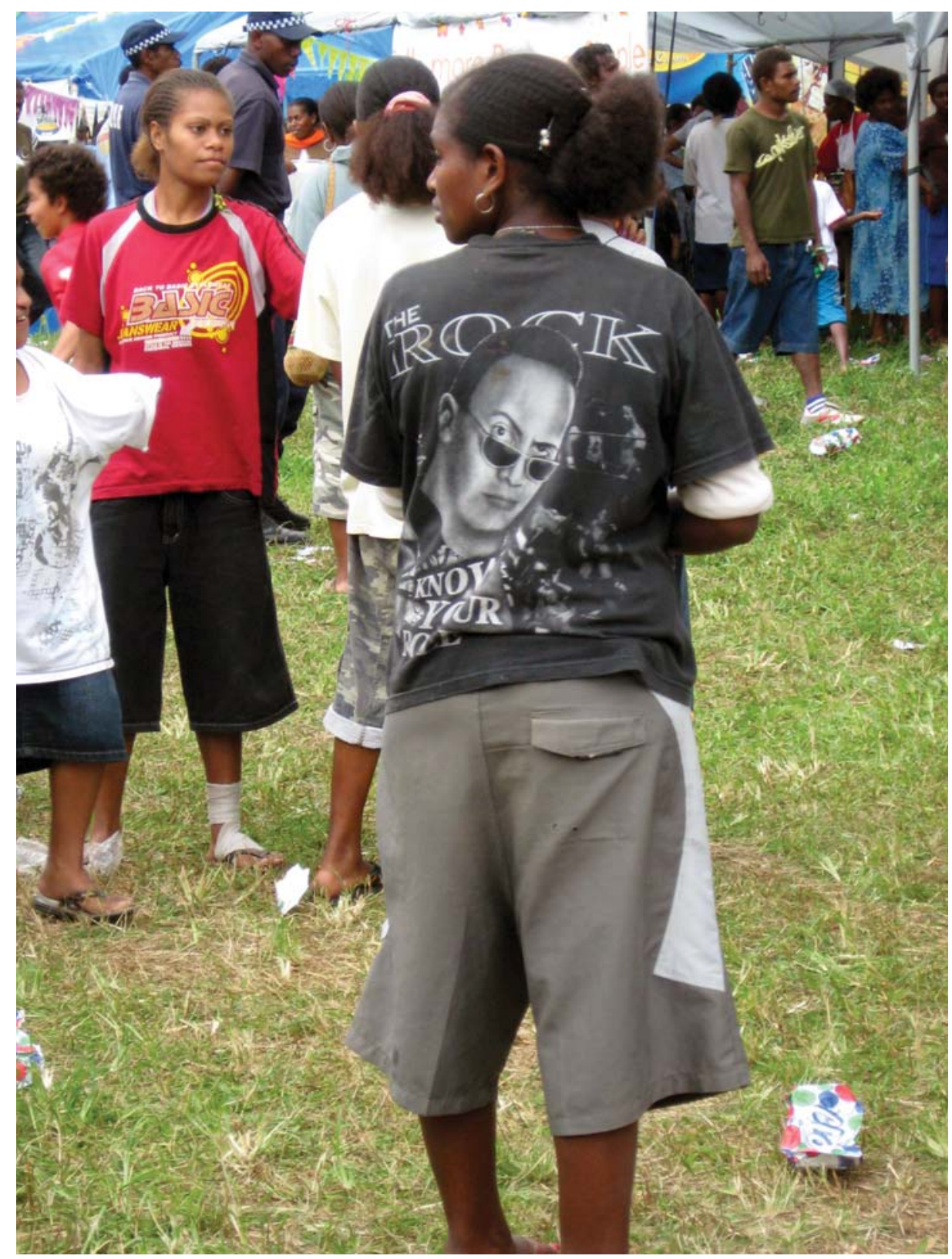

FIgURE 4 A new collective identity? Young women in large T-shirts and baggy shorts, Port Vila, I 2 July 2008 . Photo by author. 
stret fasin. Rather, it seems that the "future" they have found themselves living in is one in which establishing and reiterating a sense of national identity has less relevance than other, more pressing issues-crowded and under-resourced settlement living, the lure and hardship of an increasingly cash-based economy, and high unemployment rates. Nonetheless, I would argue that dress-and "looking good," both morally and aestheticallyremains an important means by which young women embody and invest in a sense of collective identity. One glance at a crowd of youth at any public event in Port Vila (see figure 4) would suggest that shorts and T-shirts have become a coed urban uniform of sorts. Much as their mothers did before them, contemporary ni-Vanuatu youth have taken a "foreign" style and made it their own.

My FIELDWORK WAS FUNDED by grants from Canada's Social Sciences and Humanities Research Council. I am grateful to two anonymous reviewers who gave me invaluable feedback and to the many friends and colleagues who have shared their insights on this material over the years.

\section{Notes}

I Young women, in this case, were between the ages of fifteen and twenty-five, unmarried, and most were childless.

2 Close to 50 percent of the population was under the age of twenty-five (Vanuatu National Statistics Office 2000).

3 Quai was a ni-Vanuatu teenage pop sensation at the time and remains popular today.

4 Her mother said later that Rachel, a notorious flirt, had shown off too much on the runway.

5 While I was in Vanuatu I saw parades for Independence Day, for Children's Day, and even a "Sorry" parade to express condolence for and show solidarity with the United States after 9/I I.

6 I suspect that women in grass skirts, on the other hand, would be greeted with a reverence reserved for the "truly" exotic, rather than made light of.

\section{References}

Alexeyeff, Kalissa

2008 Globalizing Drag in the Cook Islands: Friction, Repulsion, and Abjection. The Contemporary Pacific 20:I43-I6I. 
Bakhtin, Mikhail

I98 I Discourse in the Novel. In The Dialogic Imagination: Four Essays, edited by Michael Holquist and translated by Caryl Emerson and Michael Holquist, 259-422. Austin: University of Texas Press.

Bashkow, Ira

2000 "Whitemen" Are Good to Think With: How Orokaiva Morality is Reflected on Whitemen's Skin. Identities: Global Studies in Culture and Power 7 (3): 28I-332.

2006 The Meaning of Whitemen: Race and Modernity in the Orokaiva Cultural World. Chicago: University of Chicago Press.

Besnier, Niko

2002 Transgenderism, Locality, and the Miss Galaxy Beauty Pageant in Tonga. American Ethnologist 29 (3): 534-566.

Bolton, Lissant

2003a Gender, Status, and Introduced Clothing in Vanuatu. In Clothing the Pacific, edited by Chloë Colchester, I I9-I39. Oxford: Berg.

$2003 \mathrm{~b}$ Unfolding the Moon: Enacting Women's Kastom in Vanuatu. Honolulu: University of Hawai'i Press.

2005 Dressing for Transition: Weddings, Clothing and Change in Vanuatu. In The Art of Clothing: A Pacific Experience, edited by Susanne Küchler and Graeme Were, I9-3 I. London: UCL Press.

2007 "Island Dress That Belongs to Us All": Mission Dresses and the Innovation of Tradition in Vanuatu. In Body Arts and Modernity, edited by Elizabeth Ewart and Michael O'Hanlon, I65-182. Wantage, UK: Sean Kingston Publishing.

Clifford, James

$200 \mathrm{I}$ The Last Discussant. In Irony in Action: Anthropology, Practice, and the Moral Imagination, edited by James W Fernandez and Mary Taylor Huber, 253-260. Chicago: University of Chicago Press.

Colchester, Chloë

2003 Clothing the Pacific. Oxford: Berg

Corcoran, Mark

2005 Vanuatu: Island Dress. ABC radio, I 5 February. Transcript at http:// www.abc.net.au/foreign/content/2005/sI 3 I $3695 . \mathrm{htm}$

Cummings, Maggie

2005 Who Wears the Trousers in Vanuatu? In Auto-Ethnographies: The Anthropology of Academic Practices, edited by Anne Meneley and Donna J Young, 5 I-64. Peterborough, on: Broadview Press.

2008 The Trouble with Trousers: Gossip, Kastom, and Sexual Culture in Vanuatu. In Making Sense of AIDS: Culture, Sexuality, and Power in Melanesia, edited by Leslie Butt and Richard Eves, I33-I49. Honolulu: University of Hawai'i Press. 
Durham, Deborah

I999 The Predicament of Dress: Polyvalency and the Ironies of Cultural Identity. American Ethnologist 26 (2): 389-4 I I.

Fernandez, James W, and Mary Taylor Huber

200I Introduction: The Anthropology of Irony. In Irony in Action: Anthropology, Practice, and the Moral Imagination, edited by James W Fernandez and Mary Taylor Huber, I-40. Chicago: University of Chicago Press.

Forsyth, Miranda

2009 A Bird That Flies with Two Wings: Kastom and State Justice Systems in Vanuatu. Canberra: ANU E Press.

Hansen, Karen Tranberg

2000 Salaula: The World of Secondhand Clothing and Zambia. Chicago: University of Chicago Press.

Keane, Webb

2005 The Hazards of New Clothes: What Signs Make Possible. In The Art of Clothing: A Pacific Experience, edited by Susanne Küchler and Graeme Were, I-I6. London: UCL Press.

Küchler, Susanne

2003 Preface. In Clothing the Pacific, edited by Chloë Colchester, xi. Oxford: Berg.

Küchler, Susanne, and Graeme Were, editors

2005 The Art of Clothing: A Pacific Experience. London: UCL Press.

Mitchell, Margaret Jean

I998 Young People Speak: A Report on the Vanuatu Young People's Project. Port Vila: Vanuatu Cultural Centre.

Povinelli, Elizabeth

2002 The Cunning of Recognition: Indigenous Alterities and the Making of Australian Multiculturalism. Durham, NC: Duke University Press.

Rofel, Lisa

I999 Other Modernities: Gendered Yearnings in China after Socialism. Berkeley: University of California Press.

Rousseau, Benedicta

20I I Shifting Others: Kastom and Politics at the Vanuatu Cultural Centre. In Working Together in Vanuatu: Research Histories, Collaborations, Projects, and Reflections, edited by John Taylor and Nick

Taylor, John P Thieberger, 225-237. Canberra: ANU E Press.

2010 Janus and the Siren's Call: Kava and the Articulation of Gender and Modernity in Vanuatu. Journal of the Royal Anthropological Institute I6:279-296. 
Turner, Terence

I980 The Social Skin. In Not Work Alone: A Cross-Cultural View of Activities Superfluous to Survival, edited by Jeremy Cherfas and Roger Lewin, I I 2-I40. London: Temple Smith.

Vanuatu Cultural Centre

2002 Wan Naes Wan. Videorecording, 30 minutes. Port Vila: Vanuatu Young People's Project, Vanuatu Cultural Centre.

Vanuatu National Statistics Office

2000 The 1999 Vanuatu National Population and Housing Census: Main Report. Port Vila: National Statistics Office.

\section{Abstract}

In this article, I explore the contingent and contested boundaries of looking good for young women in Vanuatu and the ways in which they negotiate these boundaries. I use women's dress as a lens through which to focus on the relationships among gender, modernity, race, and morality, and I show the ways in which all four are condensed and embodied in the moral and aesthetic imperative for women to look good. In particular, I focus on the island dress, a dress first introduced by missionaries but taken up after independence as an emblem of national pride and as the traditional dress for women. Although wearing the island dress is the commonsense way for women to look good, the young women with whom I conducted fieldwork in 200I-2002 and again in 2008 and 20I I experienced a great deal of ambivalence about the dress. They often preferred to wear trousers and T-shirts, which frequently won them the disapproval of their elders. By focusing on the polyvalent meanings of the island dress, the realities of young people's everyday lives in the capital, and the uneven terrain of the dress-scape of Vanuatu, I show that young women's love/hate relationship with island dress reflects their frustration with their ambiguous place in the contemporary national imaginary.

KEYWORDS: gender, Vanuatu, race, dress, national identity, morality, modernity 